\title{
Calendar of Events 2017 Overview
}

March 8-10, 2017

$14^{\text {th }}$ Annual ENETS Conference

Barcelona, Spain

April 1-4, 2017

ENDO 2017

Orlando, FL

\section{May 19-20, 2017}

\section{Nuclear Medicine Workshop}

The new series of training in hybrid imaging is focused on the hands-on experience with PET-CT under supervision of experienced specialists; the workshop will be composed of practical training and short practical lectures. The subject of the first edition of the Workshop will be 'Chest imaging'. Details at www. alfakonferencje.pl

Kazimierz nad Wisłą, Poland

\section{May 20-22, 2017}

BNMS British Nuclear Medicine Society Spring Meeting Birmingham

\section{May 20-23, 2017}

ECE 2017 - 19 $9^{\text {th }}$ European Congress of Endocrinology Lisbon, Portugal

\section{May 25-26, 2017}

IV International Radiopharmaceutical Conference "Theranostics and personalized therapy as the future of nuclear medicine" http://uww.radiofarmacja2017.pl/

Łódź, Poland

\section{June 10-14, 2017}

SNMMi Society of Nuclear Medicine and Molecular Imaging Annual Meeting
June 23-24, 2017

$7^{\text {th }}$ Conference: Interdisciplinary Problems in Endocrinology It has been 60 years since the first radioiodine therapy was applied in Poland. Therefore, this years' edition of the conference is dedicated to radionuclide therapy and its current role in different clinical settings. It is a joint symposium of the Polish societies of: nuclear medicine, endocrinology and thyroidology. Program of the conference is available at www.symposion.pl Poznań, Poland

July 30-August 3, 2017

ESE Summer School on Endocrinology 2017

Berlin, Germany

October 12-15, 2017

$5^{\text {th }}$ Conference - Oncological Seminar

As usual, the conference is organized by Polish Society of Nuclear Medicine together with Lower Silesia Oncology Centre in Wrocław. The conference is divided into two parallel tracks: for technicians and nurses and for physicians (mainly nuclear medicine and oncologists). Different oncological topics will be presented.

Details and registration at www.ptmn.pl

Szklarska Poręba, Poland

October 21-25, 2017

EANM 2017

$30^{\text {th }}$ Annual Congress of the European Association of Nuclear Medicine

Vienna, Austria 
